\title{
Seventy genetic variations in human microsomal and soluble epoxide hydrolase genes (EPHX1 and EPHX2) in the Japanese population
}

\begin{abstract}
Human microsomal and soluble epoxide hydrolases (mEH and sEH) are enzymes that metabolize xenobiotic molecules. We screened DNA from 48 Japanese individuals for single-nucleotide polymorphisms (SNPs) in both genes by direct sequencing of the entire genomic regions containing $E P H X 1$ and $E P H X 2$, except for repetitive elements. This approach identified 33 SNPs in the EPHX1 gene; 6 of them were located in the $5^{\prime}$ flanking region, 17 in introns, 8 in exons, and 2 in the $3^{\prime}$ flanking region. In the EPHX2 gene, we identified 36 SNPs, including 4 in the $5^{\prime}$ flanking region, 24 in introns, 5 in exons, and 3 in the $3^{\prime}$ flanking region, as well as one insertion/deletion polymorphism in the $5^{\prime}$ flanking region. These variants may contribute to a more precise understanding of the nature of correlations between genotypes and disease-susceptibility phenotypes that have been postulated in regard to human microsomal and soluble epoxide hydrolases.
\end{abstract}

Key words Single-nucleotide polymorphism (SNP) Human microsomal epoxide hydrolase gene (EPHX1) . Human soluble epoxide hydrolase gene (EPHX2) . Xenobiotic-metabolizing enzymes $\cdot$ Genotype

\section{Introduction}

Epoxide hydrolases (EH, EC3.3.2.3) constitute a family of enzymes that function to hydrate simple epoxides to vicinal diols and arene oxides to trans-dihydrodiols. Epoxide hydrolases that are associated with drug metabolism are clas-

S. Saito $\cdot$ A. Iida $\cdot$ A. Sekine $\cdot$ C. Eguchi $\cdot$ Y. Miura $\cdot$ Y. Nakamura Laboratory for Genotyping, SNP Research Center, Institute of Physical and Chemical Research, Tokyo, Japan

Y. Nakamura $(\square)$

Laboratory of Molecular Medicine, Human Genome Center, Institute of Medical Science, The University of Tokyo, 4-6-1

Shirokanedai, Minato-ku, Tokyo 108-8639, Japan

Tel. +81-3-5449-5372; Fax +81-3-5449-5433

e-mail: yusuke@ims.u-tokyo.ac.jp sified into two xenobiotic-metabolizing forms, microsomal $(\mathrm{mEH})$ and soluble (sEH) (Skoda et al. 1988; Beetham et al. 1993); $\mathrm{mEH}$ can be distinguished from $\mathrm{sEH}$ on the basis of physical properties (Beetham et al. 1995).

The microsomal form of epoxide hydrolase $(\mathrm{mEH})$, localized predominantly in the endoplasmic reticulum, is encoded by the EPHX1 gene on chromosome 1q42.1 (Hartsfield et al. 1998). It catalyzes the conversion of a broad spectrum of highly reactive cytotoxic arene oxides and aliphatic epoxides to less toxic trans-dihydrodiols (Raaka et al. 1998). Polymorphisms that have been identified in the EPHX1 gene are thought to affect its enzymatic activity (Gaedigk et al. 1994; Hassett et al. 1994). For example, two variant EPHX1 alleles have been associated with altered $\mathrm{mEH}$ activity in Caucasians; in those subjects, substitution of histidine for the more common tyrosine at codon 113 in exon 3 decreased $\mathrm{mEH}$ activity, whereas substitution of arginine for histidine at codon 139 in exon 4 increased this activity, probably because those variants affected the stability of the $\mathrm{mEH}$ protein or increased the enzyme's affinity for substrates. However, when both mutations were present, the enzymatic activity was approximately normal (Hassett et al. 1994). In addition to these polymorphisms in the coding region, any variants present in the $5^{\prime}$ flanking region would also be likely to influence this enzyme's activity in humans (Raaka et al. 1998).

In contrast, the soluble form of epoxide hydrolase (sEH) is confined mainly to cytoplasm. This enzyme, encoded by the EPHX2 gene on chromosome 8p12-p21 (Larsson et al. 1995), participates in the metabolism of xenobiotic molecules, with a preference for trans-substituted epoxides, such as trans-stilbene oxide (Bjelogrlic et al. 1994; Bauer et al. 1995). Recently, Sandberg et al. (2000) identified two variant sites in the $s E H$ gene, resulting, respectively, in the substitution of arginine for glutamine in exon 8 and an insertion of arginine between codons 402 and 403 in exon 13. Although the activity of the glutamine-287 variant was similar to that of the wild type, the protein containing the arginine insertion exhibited strikingly lower activity. 
A number of investigators have examined potential associations of $\mathrm{mEH}$ genotypes with altered susceptibilities to various diseases. Results from these investigations suggest that certain $\mathrm{mEH}$ genotypes may, indeed, be associated with syndromes that include hepatocellular carcinoma (McGlynn et al. 1995), ovarian cancer (Lancaster et al. 1996), colon cancer (Harrison et al. 1999), smoking-associated cancers (Benhamou et al. 1998; Jourenkova-Mironova et al. 2000), and certain pulmonary disorders (Smith and Harrison 1997). However, the molecular basis for variations in $\mathrm{mEH}$ activity has not been characterized well.

To investigate the nature of apparent genotype/phenotype correlations for $\mathrm{mEH}$ and $\mathrm{sEH}$ more precisely, we began by searching for additional single-nucleotide polymorphisms (SNPs) in the EPHX1 and EPHX2 genes, including their promoter regions and entire introns, and report here a total of 70 genetic variations, of which 47 had not been reported before.

\section{Materials and methods}

\section{Amplification of samples}

Total genomic DNAs were isolated from peripheral leukocytes of 48 unrelated Japanese individuals by the standard phenol/chloroform extraction method. Exon-intron boundaries of the EPHXI gene were defined by comparison of genomic sequences (accession number, AC058782.8 in the GenBank database) with cDNA sequences (accession number, NM_000120.2 in the GenBank database); those of the EPHX2 gene were defined by comparison of genomic sequences (accession number, AC010856.3 in the GenBank database) with cDNA sequences of EPHX2 (accession number, AF233334.1 in the GenBank database). On the basis of the Genbank sequence information, we designed polymerase chain reaction (PCR) primers to amplify DNA fragments from both genes, excluding repetitive elements, by invoking the REPEAT MASKER computer program in the manner described by Seki et al. (2000). We used $60 \mathrm{ng}$ of DNAs from three individuals, mixed in equal amounts, for each PCR experiment. The reactions were performed as follows: initial denaturation at $94^{\circ} \mathrm{C}$ for $2 \mathrm{~min}$, followed by 35 cycles of amplification at $94^{\circ} \mathrm{C}$ for $30 \mathrm{~s}$, annealing at $60^{\circ} \mathrm{C}$ for $1 \mathrm{~min}$, and extension for $1 \mathrm{~min}$.

Direct sequencing and detection of polymorphism

Products obtained from the PCR experiments were used as templates for direct sequencing and detection of SNPs, by the fluorescent dye-terminator cycle sequencing method (ABI PRISM Big Dye Terminator Cycle Sequencing Ready Reaction kit; Perkin Elmer, CA, USA). These procedures were carried out according to methods we have described elsewhere (Ohnishi et al. 2000; Seki et al. 2000; Yamada et al. 2000). Allelic frequencies of nonsynonymous SNPs in the EPHX1 and EPHX2 genes were calculated individually from 93 unrelated Japanese individuals, respectively.

\section{Results}

By screening 96 Japanese chromosomes by direct DNA sequencing, we identified 33 SNPs in the EPHX1 gene, and 36 SNPs and one insertion/deletion polymorphism in the $E P H X 2$ gene. Figure 1 illustrates the locations of these SNPs; detailed information about nucleotide positions and substitutions is summarized in Table 1 for EPHX1 and in Table 2 for EPHX2.

Of the 33 SNPs found in EPHX1, 6 were present in the 5' flanking region, 17 in introns, 8 in exons, and 2 in the $3^{\prime}$ flanking region; 25 of the total were transitions and the remaining 8 were transversions. Of the 8 SNPs found in exons, 2 caused substitutions of amino acids (Tyr113His in exon 3 and His139Arg in exon 4). Both of these variants had been reported previously (Hassett et al. 1994).

Of the 36 SNPs detected in EPHX2, 4 were located in the $5^{\prime}$ flanking region, 24 in introns, 5 in exons, and 3 in

Table 1. Summary of SNPs detected in the EPHX1 gene

\begin{tabular}{|c|c|c|c|}
\hline SNP no. & Location & Position $^{a}$ & SNP \\
\hline 1 & 5' Flanking & -699 & $\mathrm{C} / \mathrm{T}^{\mathrm{b}}$ \\
\hline 2 & 5' Flanking & -613 & $\mathrm{~T} / \mathrm{C}^{\mathrm{b}}$ \\
\hline 3 & 5' Flanking & -362 & $\mathrm{G} / \mathrm{A}^{\mathrm{b}}$ \\
\hline 4 & 5' Flanking & -290 & $\mathrm{G} / \mathrm{T}^{\mathrm{b}}$ \\
\hline 5 & 5' Flanking & -259 & $\mathrm{~T} / \mathrm{C}^{\mathrm{b}}$ \\
\hline 6 & 5' Flanking & -200 & $T / C^{b}$ \\
\hline 7 & Exon 1 & 66 & $\mathrm{G} / \mathrm{A}\left(5^{\prime} \mathrm{UTR}\right)^{\mathrm{c}}$ \\
\hline 8 & Intron 1 & 110 & $\mathrm{C} / \mathrm{T}$ \\
\hline 9 & Intron 1 & 143 & G/A \\
\hline 10 & Intron 1 & 1097 & $\mathrm{~T} / \mathrm{G}$ \\
\hline 11 & Intron 1 & 1717 & $\mathrm{~T} / \mathrm{C}$ \\
\hline 12 & Intron 1 & 1772 & $\mathrm{G} / \mathrm{T}$ \\
\hline 13 & Intron 1 & 2054 & $\mathrm{~A} / \mathrm{G}$ \\
\hline 14 & Intron 1 & 2114 & $\mathrm{C} / \mathrm{T}^{\mathrm{d}}$ \\
\hline 15 & Intron 1 & 2287 & $\mathrm{C} / \mathrm{G}^{\mathrm{d}}$ \\
\hline 16 & Intron 2 & 1414 & $\mathrm{G} / \mathrm{T}$ \\
\hline 17 & Intron 2 & 1514 & $\mathrm{~A} / \mathrm{G}^{\mathrm{d}}$ \\
\hline 18 & Exon 3 & 154 & $\mathrm{~T} / \mathrm{C}(\mathrm{Ty} 113 \mathrm{His})^{\mathrm{d}, \mathrm{e}}$ \\
\hline 19 & Exon 3 & 174 & G/A(Lys119Lys) \\
\hline 20 & Intron 3 & 6583 & $\mathrm{G} / \mathrm{C}$ \\
\hline 21 & Exon 4 & 52 & A/G(His139Arg) \\
\hline 22 & Intron 4 & 34 & $\mathrm{G} / \mathrm{A}$ \\
\hline 23 & Intron 4 & 63 & $\mathrm{C} / \mathrm{T}$ \\
\hline 24 & Intron 5 & 154 & G/A \\
\hline 25 & Intron 5 & 276 & $\mathrm{~T} / \mathrm{C}$ \\
\hline 26 & Exon 6 & 130 & C/T(Pro284Pro) \\
\hline 27 & Exon 8 & 31 & $\mathrm{C} / \mathrm{T}(\mathrm{Asn} 357 \mathrm{Asn})^{\mathrm{c}}$ \\
\hline 28 & Intron 8 & 206 & $\mathrm{C} / \mathrm{A}$ \\
\hline 29 & Intron 8 & 353 & $\mathrm{~A} / \mathrm{G}$ \\
\hline 30 & Exon 9 & 82 & G/A(Lys416Lys) ${ }^{c}$ \\
\hline 31 & Exon 9 & 184 & $\mathrm{G} / \mathrm{C}(\operatorname{Ser} 450 \mathrm{Ser})^{\mathrm{c}}$ \\
\hline 32 & 3' Flanking & 212 & $\mathrm{~A} / \mathrm{G}^{\mathrm{d}}$ \\
\hline 33 & 3' Flanking & 708 & $\mathrm{~A} / \mathrm{G}$ \\
\hline
\end{tabular}

SNP, single nucleotide polymorphism

${ }^{a}$ For SNPs in the 5' flanking region, intron region, or 3' flanking region, nucleotide positions are counted from the first intronic nucleotide at the exon/intron junction (for SNPs in the exon region, nucleotide positions are counted from the first exonic nucleotide at the exon/intron junction)

${ }^{\mathrm{b}}$ SNPs previously reported by Raaka et al. (1998)

${ }^{\mathrm{c}} \mathrm{SNPs}$ previously reported in the GenBank database

${ }^{\mathrm{d}} \mathrm{SNPs}$ previously reported in the dbSNP database

${ }^{\mathrm{e}} \mathrm{SNPs}$ previously reported by Hassett et al. (1994) 
(A)

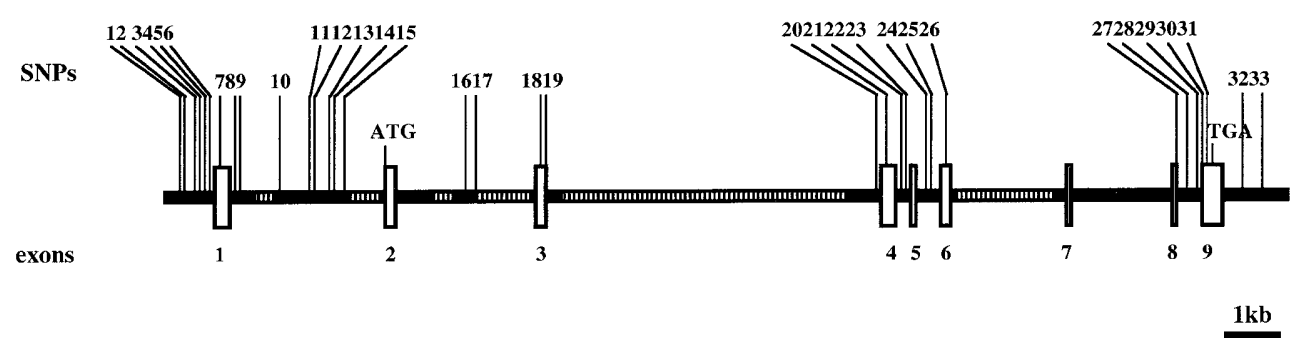

(B)

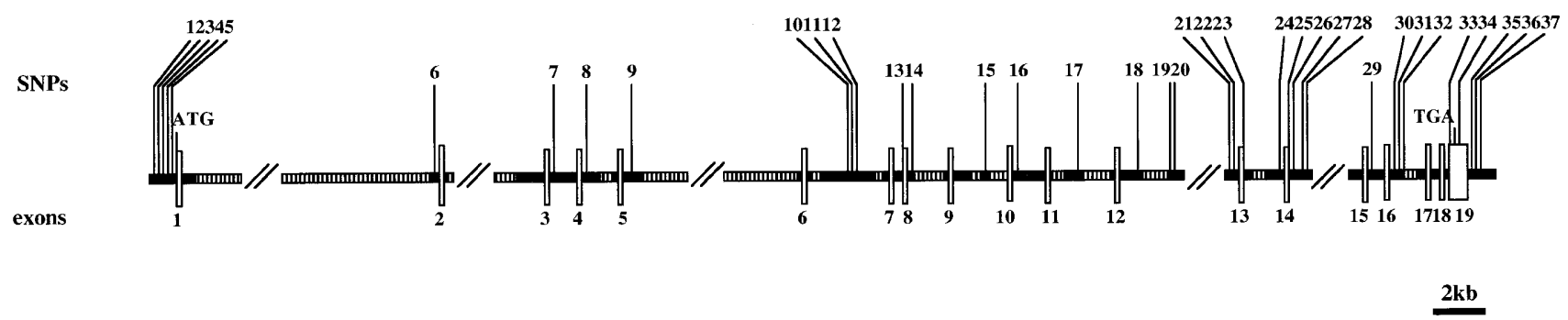

Fig. 1A,B. Locations of single-nucleotide polymorphisms ( $S N P s)$ in $\mathbf{A}$ the EPHX1 and B EPHX2 genes, indicated by vertical lines. Open boxes represent exons; hatching on the chromosomes indicates regions

of repetitive elements. $A T G$ and $T G A$, Initiation and stop codons, respectively the $3^{\prime}$ flanking region; 27 were transitions and 9 were transversions. Among the five variant sites present in exons, two would cause amino acid substitutions, Arg287Gln in exon 8 and Ser407Ile in exon 13.

\section{Discussion}

We identified 33 SNPs in the EPHX1 gene, of which 17 were novel. Two of these 33 SNPs would substitute amino acids, Tyr113His in exon 3 and His139Arg in exon 4, but both of these variants had been reported previously (Hassett et al. 1994). Recently, Belmahdi et al. (2000) reported two additional nonsynonymous polymorphisms in the $E P H X 1$ gene among 150 French individuals; one caused an Arg49Cys substitution in exon 2 (the frequency of the minor allele was $0.67 \%$ ) and the other, an Arg454Gln substitution in exon 9 (the frequency of the Gln allele was $0.73 \%)$. We found neither of these variants among the 93 Japanese individuals we screened. Although the biological significance of the French polymorphisms is unclear, they must be considered very rare substitutions.

On the basis of evidence that, in two of the variant $E P H X 1$ alleles, substitutions of histidine for tyrosine at codon 113 and arginine for histidine at codon 139 were associated with altered $\mathrm{mEH}$ activity in Caucasians (Hassett et al. 1994), potential associations between $\mathrm{mEH}$ genotypes and susceptibility to certain diseases have been investigated in various laboratories. Although some findings have suggested an association with risk for carcinomas of liver, ovary, colon, and lung, as well as emphysema (McGlynn et al. 1995; Lancaster et al. 1996; Smith et al. 1997; Benhamou et al. 1998; Harrison et al. 1999; Jourenkova-Mironova et al. 2000), no conclusive results have emerged. Because the molecular basis for genetic variations in $\mathrm{mEH}$ activity has not yet been well characterized, additional studies to examine potential relationships between $\mathrm{mEH}$ allelic status and susceptibility to certain diseases will be required to clarify any potential associations. The novel SNPs in EPHX1 published here will contribute to investigations of that kind.

Among the 37 genetic variations found in the EPHX2 gene, 30 variants, including a nonsynonymous SNP (Ser407Ile) were novel. Recently, Sandberg et al. (2000) reported eight variants in $E P H X 2 \mathrm{cDNA}$, of which two led to amino-acid substitutions (Arg287Gln and $\mathrm{Arg}^{402-403 i n s}$ ). The sEH protein containing the arginine insertion exhibited a strikingly lower activity, but the activity of the $287 \mathrm{Gln}$ variant was similar to that of the wild type. In the Japanese population, we found no $\mathrm{Arg}^{402-403 i n s}$ in any of the 92 individuals examined; instead, we found a novel Ser407Ile substitution in only 1 of these 184 chromosomes (allelic frequency of $0.54 \%$ ) although its biological effect is unknown. We consider this variant to be a rare substitution in the Japanese population. 
Table 2. Summary of genetic variations detected in the $E P H X 2$ gene

\begin{tabular}{|c|c|c|c|}
\hline SNP no. & Location & Position $^{\mathrm{a}}$ & SNP \\
\hline 1 & $5^{\prime}$ Flanking & $-(523-522)$ & insC \\
\hline 2 & $5^{\prime}$ Flanking & -522 & $\mathrm{~T} / \mathrm{C}$ \\
\hline 3 & 5' Flanking & -521 & $\mathrm{C} / \mathrm{T}$ \\
\hline 4 & 5' Flanking & -516 & $\mathrm{G} / \mathrm{C}$ \\
\hline 5 & 5' Flanking & -515 & $\mathrm{C} / \mathrm{G}$ \\
\hline 6 & Intron 1 & -74 & $\mathrm{~T} / \mathrm{C}$ \\
\hline 7 & Intron 3 & 72 & $\mathrm{~T} / \mathrm{C}$ \\
\hline 8 & Intron 4 & 473 & $\mathrm{~A} / \mathrm{G}$ \\
\hline 9 & Intron 5 & 276 & $\mathrm{C} / \mathrm{T}$ \\
\hline 10 & Intron 6 & 2150 & $\mathrm{G} / \mathrm{A}^{\mathrm{b}}$ \\
\hline 11 & Intron 6 & 2181 & $\mathrm{G} / \mathrm{A}^{\mathrm{b}}$ \\
\hline 12 & Intron 6 & 2185 & $\mathrm{~A} / \mathrm{G}^{\mathrm{b}}$ \\
\hline 13 & Exon 8 & 29 & $\mathrm{G} / \mathrm{A}(\operatorname{Arg} 287 \mathrm{Gln})^{\mathrm{b}, \mathrm{c}}$ \\
\hline 14 & Intron 8 & 8 & $\mathrm{~T} / \mathrm{C}$ \\
\hline 15 & Intron 9 & 1573 & $\mathrm{C} / \mathrm{T}$ \\
\hline 16 & Intron 10 & 207 & $\mathrm{~T} / \mathrm{C}$ \\
\hline 17 & Intron 11 & 1173 & $\mathrm{G} / \mathrm{C}^{\mathrm{b}}$ \\
\hline 18 & Intron 12 & 911 & $\mathrm{G} / \mathrm{T}$ \\
\hline 19 & Intron 12 & 2425 & $\mathrm{C} / \mathrm{T}$ \\
\hline 20 & Intron 12 & 2460 & $\mathrm{G} / \mathrm{A}$ \\
\hline 21 & Intron 12 & -281 & $\mathrm{~T} / \mathrm{C}$ \\
\hline 22 & Intron 12 & -268 & $\mathrm{~T} / \mathrm{G}$ \\
\hline 23 & Exon 13 & 50 & G/T(Ser407Ile) \\
\hline 24 & Intron 13 & 1739 & $\mathrm{G} / \mathrm{T}$ \\
\hline 25 & Exon 14 & 33 & G/A(Ala425Ala) \\
\hline 26 & Intron 14 & 314 & $\mathrm{~T} / \mathrm{C}$ \\
\hline 27 & Intron 14 & 878 & $\mathrm{C} / \mathrm{T}$ \\
\hline 28 & Intron 14 & 948 & $\mathrm{~T} / \mathrm{C}$ \\
\hline 29 & Intron 15 & 259 & $\mathrm{C} / \mathrm{T}$ \\
\hline 30 & Intron 16 & 459 & $\mathrm{G} / \mathrm{C}$ \\
\hline 31 & Intron 16 & 645 & G/A \\
\hline 32 & Intron 16 & 985 & $\mathrm{G} / \mathrm{A}$ \\
\hline 33 & Exon 19 & 4 & $\mathrm{~A} / \mathrm{C}(\text { Pro531Pro })^{\mathrm{c}}$ \\
\hline 34 & Exon 19 & 114 & $\mathrm{G} / \mathrm{A}\left(3^{\prime} \mathrm{UTR}\right)^{\mathrm{c}}$ \\
\hline 35 & 3' Flanking & 12 & $\mathrm{~T} / \mathrm{C}$ \\
\hline 36 & $3^{\prime}$ Flanking & 374 & $\mathrm{C} / \mathrm{T}$ \\
\hline 37 & 3' Flanking & 544 & $\mathrm{G} / \mathrm{A}$ \\
\hline
\end{tabular}

SNP, single nucleotide polymorphism

${ }^{\text {a }}$ For SNPs in the 5' flanking region, intron region, or 3' flanking region, nucleotide positions are counted from the first intronic nucleotide at the exon/intron junction (for SNPs in the exon region, nucleotide positions are counted from the first exonic nucleotide at the exon/intron junction)

${ }^{b}$ SNPs previously reported in the dbSNP database

${ }^{\mathrm{c}} \mathrm{SNPs}$ previously reported by Sandberg et al. (2000)

In addition to the five genetic variations in the $5^{\prime}$ flanking region of $E P H X 2$, we also found a CA microsatellite polymorphism (data not shown). Because variants that are present upstream of either gene may effect transcriptional efficiency, they, and the other SNPs published here, should be useful for examining the relationships between an individual's EH genotype and his or her susceptibility to certain diseases.

\section{References}

Bauer E, Guo Z, Ueng YF, Bell LC, Zeldin D, Guengerich FP (1995) Oxidation of benzo[a]pyrene by recombinant human cytochrome P450 enzymes. Chem Res Toxicol 8:136-142
Beetham JK, Grant D, Arand M, Garbarino J, Kiyosue T, Pinot F, Oesch F, Belknap WR, Shinozaki K, Hammock BD (1995) Gene evolution of epoxide hydrolases and recommended nomenclature. DNA Cell Biol 14:61-71

Beetham JK, Tian T, Hammock BD (1993) cDNA cloning and expression of a soluble epoxide hydrolase from human liver. Arch Biochem Biophys 305:197-201

Belmahdi F, Chevalier D, Lo-Guidice JM, Allorge D, Cauffiez C, Lafitte JJ, Broly F (2000) Identification of six new polymorphisms, g. $11177 \mathrm{G}>\mathrm{A}$, g. $14622 \mathrm{C}>\mathrm{T}(\mathrm{R} 49 \mathrm{C})$, g. $17540 \mathrm{~T}>\mathrm{C}, \mathrm{g} .17639 \mathrm{~T}>\mathrm{C}$, g. 30929T > C, g. 31074G > A (R454Q), in the human microsomal epoxide hydrolase gene $(E P H X 1)$ in a French population. Hum Mutat 16:450

Benhamou S, Reinikainen M, Bouchardy C, Dayer P, Hirvonen A (1998) Association between lung cancer and microsomal epoxide hydrolase genotypes. Cancer Res 58:5291-5293

Bjelogrlic NM, Makinen M, Stenback F, Vahakangas K (1994) Benzo[a]pyrene-7,8-diol-9,10-epoxide-DNA adducts and increased p53 protein in mouse skin. Carcinogenesis 15:771-774

Gaedigk A, Spielberg SP, Grant DM (1994) Characterization of the microsomal epoxide hydrolase gene in patients with adverse anticonvulsant drug reactions. Pharmacogenetics 4:142-153

Harrison DJ, Hubbard AL, MacMillan J, Wyllie AH, Smith CA (1999) Microsomal epoxide hydrolase gene polymorphism and susceptibility to colon cancer. Br J Cancer 79:168-171

Hartsfield JK Jr, Sutcliffe MJ, Everett ET, Hassett C, Omiecinski CJ, Saari JA (1998) Assignment of microsomal epoxide hydrolase (EPHX1) to human chromosome 1q42.1 by in situ hybridization. Cytogenet Cell Genet 83:44-45

Hassett C, Aicher L, Sidhu JS, Omiecinski CJ (1994) Human microsomal epoxide hydrolase: genetic polymorphism and functional expression in vitro of amino acid variants. Hum Mol Genet 3:421-428

Jourenkova-Mironova N, Mitrunen K, Bouchardy C, Dayer P, Benhamou S, Hirvonen A (2000) High-activity microsomal epoxide hydrolase genotypes and the risk of oral, pharynx, and larynx cancers. Cancer Res 60:534-536

Lancaster JM, Brownlee HA, Bell DA, Futreal PA, Marks JR, Berchuck A, Wiseman RW, Taylor JA (1996) Microsomal epoxide hydrolase polymorphism as a risk factor for ovarian cancer. Mol Carcinog 17:160-162

Larsson C, White I, Johansson C, Stark A, Meijer J (1995) Localization of the human soluble epoxide hydrolase gene (EPHX2) to chromosomal region 8p21-p12. Hum Genet 95:356-358

McGlynn KA, Rosvold EA, Lustbader ED, Hu Y, Clapper ML, Zhou T, Wild CP, Xia XL, Baffoe-Bonnie A, Ofori-Adjei D, Chen GC, London WT, Shen FM, Buetow KH (1995) Susceptibility to hepatocellular carcinoma is associated with genetic variation in the enzymatic detoxification of aflatoxin $B_{1}$. Proc Natl Acad Sci USA 92:2384-2387

Ohnishi Y, Tanaka T, Yamada R, Suematsu K, Minami M, Fujii K, Hoki N, Kodama K, Nagata S, Hayashi T, Kinoshita N, Sato H, Sato Hid, Kuzuya T, Takeda H, Hori M, Nakamura Y (2000) Identification of 187 single nucleotide polymorphisms (SNPs) among 41 candidate genes for ischemic heart disease in the Japanese population. Hum Genet 106:288-292

Omiecinski CJ, Hassett C, Hosagrahara V (2000) Epoxide hydrolase polymorphism and role in toxicology. Toxicol Lett 112-113:365-370

Raaka S, Hassett C, Omiencinski CJ (1998) Human microsomal epoxide hydrolase: $5^{\prime}$-flanking region genetic polymorphisms. Carcinogenesis 19:387-393

Sandberg M, Hassett C, Adman ET, Meijer J, Omiecinski CJ (2000) Identification and functional characterization of human soluble epoxide hydrolase genetic polymorphisms. J Biol Chem 275:2887328881

Seki T, Tanaka T, Nakamura Y (2000) Genomic structure and multiple single-nucleotide polymorphisms (SNPs) of the thiopurine Smethyltransferase (TPMT) gene. J Hum Genet 45:299-302

Skoda RC, Demierre A, McBride OW, Gonzalez FJ, Meyer UA (1988) Human microsomal xenobiotic epoxide hydrolase. Complementary DNA sequence, complementary DNA-directed expression in COS-1 cells, and chromosomal localization. J Biol Chem 263:1549_ 1554

Smith CA, Harrison DJ (1997) Association between polymorphism in the gene for microsomal epoxide hydrolase and susceptibility to emphysema. Lancet 350:630-633 
Yamada R, Tanaka T, Ohnishi Y, Suematsu K, Minami M, Seki T, Yukiok M, Maeda A, Murata N, Saiki O, Teshima R, Kudo O, Ishikawa K, Ueyosi A, Tateishi H, Inaba M, Goto H, Nishizawa Y, Tohma S, Ochi T, Yamamoto K, Nakamura Y (2000) Identification of 142 single nucleotide polymorphisms in 41 candidate genes for rheumatoid arthritis in the Japanese population. Hum Genet 106:293-297 